\title{
МАТЕМАТИЧНА МОДЕЛЬ «РОЗМІЩЕННЯ МЕТАЛОПРОКАТУ НА СКЛАДАХ ГОТОВОї ПРОДУКЦЇ̈»
}

У статті наводиться опис математичної моделі розміщення металопрокату на складах готової продукиії. Математична модель дасть можливість при приході металопрокату на склад по кожній позииії провести пошук відповідного місия розміщення, з урахуванням категорії АВС-аналізу, геометричних особливостей, способу зберігання $i$ кількості металопрокату. АВС-аналіз на складі-метод, що дозволяє класифікувати запаси металопрокату за ступенем їх важливості иляхом ділення на три категорії. $B$ якості критерію класифікації запропоновано використовувати коефіцієнт оборотності металопрокату.

Наведено алгоритм розмішення металопрокату на частково заповненому складі. Вибір сектору для розмішення визначається за найменшим значенням завантаженості в поточний момент часу. Цільове зберігання номенклатури в одному місиі зберігання - не більше 2-х позищій. При розрахунку враховується наявність сепаращії (дерев'яних прокладок) між пачками номенклатурних позищій. Цільове значення по ширині складської площі - один метр між чотирма місиями зберігання. Цільове значення по довжині складської площі - один метр між місиями зберігання. Розподіл складів на сектора враховує зони зберігання інвентарю та зони сервісної обробки (різання) продукиії.

Для оцінки ефективності математичної моделі введені наступні коефіцієнти: коефіиієнт використання площуі складських приміщень, коефійієнт використання об'єму складу, вантажонапруженість номенклатури.

Ключові слова: металопрокат, склад, математична модель, АВС аналіз, коефічієнт ефективності

Вступ. Складське господарство $є$ одним 3 найважливіших елементів логістичної системи, який має місце на будь-якому етапі руху матеріального потоку від первинного джерела сировини до кінцевого споживача. Переміщення потоків в логістичному ланцюгу вимагає концентрації у певних місцях необхідних запасів, для зберігання яких і призначені склади. У зв'язку з цим проблеми, пов'язані з функціонуванням складів, мають значний вплив на раціоналізацію руху матеріальних потоків в логістичному ланцюзі, використання транспортних засобів і витрат обігу.

Складське господарство підприємства «Метінвест-СМЦ», яке націлене на випередження конкурентів, вимагає сучасної організації, нових інформаційних технологій і кваліфікованих кадрів. Важливо здійснювати комплексний облік металопрокату, моніторинг його запасів, контроль дій персоналу. Основна складова оптимізації складських господарств - автоматизація пов'язаних 3 ними бізнес-процесів, що дозволяє ефективно управляти запасами, знижувати витрати при плануванні майбутніх поставок, оптимізувати використання складських площ, підвищувати точність і оперативність обліку продукції, що зберігається, а також продуктивність праці працівників складу i контролюючого менеджменту [1, 2].

Аналіз останніх досліджень і публікацій. Склади грають велику роль в мережах доставки вантажів від місць виробництв до кінцевих споживачів, будучи системоутворюючими елементами цих мереж [3, 4]. При розміщенні продукції на складі одним з основних питань $є$ обгрунтований вибір величини місткості складу, оскільки від

Режим доступу: http://sap.pstu.edu 


\section{Інформаційні технології}

цього залежать всі інші технічні рішення $[5,6]$. При проектуванні зони зберігання потрібно вибрати раціональний спосіб складування вантажів, тип і параметри стелажного обладнання. При цьому раціональний спосіб складування - такий, при якому забезпечується найбільш повне заповнення зони зберігання і мінімальне переміщення вантажу [7, 8].

Метою даної статті є публікація математичної моделі «Розміщення металопрокату на складах готової продукції», яка в подальшому буде використана при розробці рекомендуючої системи розміщення металопрокату або інтелектуальної системи управління складом.

Математична модель розміщення металопрокату на складах готової продукції. Один 3 головних показників ефективності роботи складського підприємства - оборотність запасів металопрокату. Коефіцієнт оборотності запасів - це співвідношення відвантажень складу до його активів (залишків). Цей показник дає зрозуміти, як швидко витрачається запас, що лежить на складі. За коефіцієнтом оборотності запасів можна зрозуміти наскільки ефективно і успішно підприємство використовує свої активи для отримання доходів.

Для підрахунку коефіцієнта оборотності потрібно мати три параметра:

Р - період;

$\mathrm{T}_{\mathrm{cp}}^{3}$ - середній запас металопрокату за період;

$\mathrm{V}^{\mathrm{O}}$ - обсяг відвантаження металопрокату за період.

Дуже часто при підрахунку коефіцієнта оборотності тут виникає плутанина. Багато хто вважає:

- не середній запас, а запас на «сьогодні». Це рівень запасів, і показує цей метод не оборотність, а то, скільки днів залишилося до кінця відвантажень зі складу, тобто «наскільки вистачить запасу тієї чи іншої номенклатури». Даний параметр не відображає динаміку;

- середній запас, але неправильно. Беруть перший день періоду і останній день, i ділять навпіл. Це невірно, тому що не відображає динаміку запасів протягом всього періоду.

Протягом періоду можуть виникати ситуації дефіциту і перевантаження складу певним металопрокатом. Тому для розрахунку середнього товарного запасу конкретного металопрокату по точках виміру розташованим через рівні проміжки часу, необхідно використовувати формулу (1):

$$
\mathrm{T}_{\mathrm{cp}}^{3}=\frac{\frac{\mathrm{T}_{1}^{3}}{2}+\mathrm{T}_{2}^{3}+\mathrm{T}_{3}^{3}+\mathrm{T}_{4}^{3}+\ldots+\frac{\mathrm{T}_{\mathrm{n}}^{3}}{2}}{\mathrm{n}-1}
$$

де $\mathrm{T}_{1}^{3}, \mathrm{~T}_{2}^{3}, \ldots \mathrm{T}_{\mathrm{n}}^{3}$ - величина запасу металопрокату на окремі дати аналізованого періоду в тонах;

$\mathrm{n}$ - кількість дат в періоді.

Як було сказано раніше, перш за все, необхідно визначиться $з$ періодом - це може бути тиждень, місяць, квартал, рік. На окремих складах ТОВ «Метінвест-СМЦ» найдоцільніше в якості періоду приймати величину - тиждень, на окремих - місяць, це залежить від інтенсивності надходження і витрати металопрокату. Якщо відвантаження i прихід металопрокату здійснюються хоча б раз в день (до уваги беруться тільки робочі дні), то інтенсивність висока і період береться за тиждень, а якщо відвантаження здійснюються один два рази на місяць, то доцільніше прийняти період за місяць, а то й за квартал.

Величина $\mathrm{T}_{\mathrm{n}}^{3}$ відповідає залишку певного металопрокату на поточний момент часу, для визначення $\mathrm{T}_{\mathrm{n}-1}^{3}$ необхідно скористатися формулою (2):

Режим доступу: http://sap.pstu.edu 
$2019 \mathrm{p}$.

Інформаційні технології

Вип. 20

$$
\mathrm{T}_{\mathrm{n}-1}^{3}=\mathrm{T}^{3}-\sum_{\mathrm{n}-1} \mathrm{O}+\sum_{\mathrm{n}-1} \Pi
$$

де $\sum_{n-1} \mathrm{O}$ - сума всіх відвантажень даного металопрокату протягом $\mathrm{n}-1$ дати (вимірюється в тонах); тонах).

$\sum_{n-1} \mathrm{O}$ - сума всіх приходів даного металопрокату протягом $\mathrm{n}-1$ дати (вимірюється в

Дана формула (2) є ітераційною, тому зміщуючись на одну дату можна отримати попередній показник залишку металопрокату. Таким чином, проводячи циклічний зсув по всім датам періоду (від n-1 дати до 1) ми отримаємо безліч залишків за всіма датами.

Для розрахунку обсягу відвантажень металопрокату за період (в тонах) скористаємося формулою (3):

$$
\mathrm{V}^{\mathrm{O}}=\sum_{\mathrm{i}=1}^{\mathrm{n}} \mathrm{O}_{\mathrm{i}}
$$

де $\mathrm{O}_{\mathrm{i}}$ - сума всіх відвантажень протягом i-ой дати (в тонах) для конкретного металопрокату.

Звідси, коефіцієнт оборотності металопрокату, що відображає кількість оборотів, яку здійснюють запаси металопрокату за звітний період, може бути знайдено за формулою (2.4):

$$
\mathrm{K}^{\mathrm{o \sigma}}=\frac{\mathrm{V}^{\mathrm{O}}}{\mathrm{T}_{\mathrm{cp}}^{3}}
$$

Отриманий коефіцієнт оборотності металопрокату буде використаний, як критерій класифікації в АВС аналізі.

ABC класифікація (АВС аналіз). Ідея $\mathrm{ABC}$-аналізу будується на основі принципу Парето, який формулюється так: «20\% зусиль дають $80 \%$ результату, а інші $80 \%$ зусиль лише $20 \%$ результату», тобто $20 \%$ всіх товарів дають $80 \%$ обороту. Застосовуючи це правило до товарів будь-якої торговельної компанії, можна зробити дуже простий крок, щодо впровадження логістики [9,10].

ABC-аналіз на складі - метод, що дозволяє класифікувати запаси металопрокату за ступенем їх важливості шляхом ділення на три категорії. Класичні кордони наступні:

А - основний, $20 \%$ - запасів металопрокату; $80 \%$ - відвантажень;

В - тимчасовий, $30 \%$ - запасів металопрокату; $15 \%$ - відвантажень;

3 - вимушений, 50 \% - запасів металопрокату; 5 \% - відвантажень.

Основний запас металопрокату служить для забезпечення поточного відвантаження відповідно до плану.

Тимчасовий запас створюється для отримання додаткових конкурентних переваг.

Вимушений запас виникає сам по собі в процесі роботи будь-якої компанії.

Проведення АВС-класифікації включає ряд етапів:

1. Вибір критерію класифікації.

Режим доступу: http://sap.pstu.edu 


\section{Інформаційні технології}

2. Розрахунок наростаючого підсумку значення критерію класифікації.

3. Виділення класифікаційних груп.

Перший етап $є$ єдиним неформалізованим кроком класифікації. Вибір критерію класифікації залежить, перш за все, від стратегії підприємства, який відпрацьовується на даному етапі розвитку. Для кожного з функціональних підрозділів підприємства діюча стратегія може бути пов'язана з реалізацією специфічного для даного підрозділу напрямку роботи.

Вибір критерію АВС-класифікації, таким чином, вимагає спільного обговорення цього питання 3 керівниками вищого рівня і з керівниками підрозділів, пов'язаних один 3 одним логістичним ланцюгом руху матеріального потоку. Чи буде на підприємстві використовуватися один або кілька (для кожної функціональної області логістики - свій) критеріїв класифікації є завданням, пов'язаним з реалізацією заданої стратегії підприємства. Недолік уваги до цього етапу класифікації зведе нанівець всі зусилля використання цього інструменту в практиці управління діяльністю організації в цілому.

В якості критерію класифікації нами пропонується використовувати отриманий коефіцієнт оборотності металопрокату.

Виконання другого кроку АВС-класифікації включає складання рейтингового списку номенклатурних позицій по спаданню значення критерію класифікації (вгорі розташовується металопрокат 3 найбільшим коефіцієнтом оборотності, внизу - 3 найменшим) і проведення розрахунку частки критерію класифікації від загальної суми по номенклатурним позиціям за формулою (5) .

$$
\mathrm{d}_{\mathrm{j}}=\frac{\mathrm{K}_{\mathrm{j}}^{\mathrm{O}}}{\sum_{\mathrm{i}=1}^{\mathrm{m}} \mathrm{K}_{\mathrm{i}}^{0}}, \forall \mathrm{j} \in[1, \mathrm{~m}]
$$

де m - кількість позицій металопрокату в списку для АВС-класифікації;

$K_{j}^{O}$ - коефіцієнт оборотності ј-го металопрокату.

Потім необхідно розрахувати цю частку 3 накопичувальним підсумком $\mathrm{d}^{\mathrm{H}}$ (для зручності подальшого визначення меж для груп АВС). Для першого металопрокату вона буде ідентична раніш розрахованій індивідуальній частці $-\mathrm{d}_{1}^{\mathrm{H}}=\mathrm{d}_{1}$. Наступні накопичені частки розраховуються підсумовуванням відповідної індивідуальної частки 3 накопиченою для попередньої позиції. Тобто накопичена частка металопрокату ј буде дорівнює (6):

$$
d_{j}^{H}=d_{j-1}^{H}+d_{j}, \forall j \in[2, m]
$$

Третій крок - виділення груп класифікації. Металопрокат в списку з першої позиції по позицію, у якій $d_{j}^{\mathrm{H}}=80 \%$ буде віднесений до групи $\mathrm{A}, 3 \mathrm{j}+1$ позиції до $d_{s}^{\mathrm{H}}=95 \%-$ до групи В і залишився список $3 \mathrm{~s}+1$ позиції і до кінця списку - група C.

Розміщення металопрокату на частково заповненому складі. Перелік номенклатури для розміщення представляється у вигляді інформаційної структури (форма, найменування, матеріал, марка сталі, фактичні розміри, СМЦ, завод, склад, залишок, продажна одиниця). Перед розміщенням на складі необхідно в даний перелік додати групу $\mathrm{ABC}$ аналізу, для чого проводиться розрахунок з використанням методики, яка описана раніше. 
$2019 \mathrm{p}$.

\section{Інформаційні технології}

Вип. 20

Після проведення обчислень (5) - (6) для кожної позиції переліку номенклатури буде приписана група АBC аналізу.

Розвантаження металопрокату проходить, відповідно до того, як він укладений в транспортному засобі, оператор системи (комірник складу) вводить в систему код або найменування верхнього металопрокату і система вибирає для нього необхідну позицію розміщення.

Допускається вказати оператору номер сектора для розміщення. Якщо даний параметр буде опущений, система пропонує помістити металопрокат в секторі, який має найменшу завантаженість в поточний момент часу. Вибір найменш завантаженого сектора обумовлений рівномірністю завантаження складу в цілому. Так відвантаження рекомендується системою 3 сектора, який найбільш перевантажений.

Для визначення завантаженості сектора складу використовується формула (7).

$$
3_{j}^{\text {сек }}=\frac{S_{j}^{\text {зан }}}{S_{j}^{\text {общ }}}
$$

де $S_{j}^{\text {зан }}$ - корисна площа, зайнята під складування, в ј-му секторі складу $\left(\right.$ в м $\left.{ }^{2}\right)$;

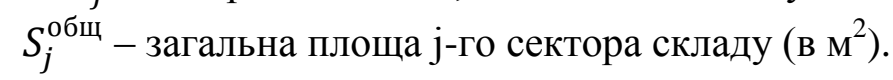

Номер сектора складу для розміщення вибирається за формулою (8):

$$
N^{\text {сек }}=\min _{j} 3_{j}^{\text {сек }}
$$

Після того, як сектор визначено в системі відбувається завантаження схеми розміщення номенклатур для $N^{\text {сек }}$ сектора складу. Дана схема являє собою таблицю розмірності $\mathrm{m}$ стовпців на $\mathrm{n}$ рядків, де $\mathrm{m}$ i $\mathrm{n}$ рівні всій довжині і ширині сектора в метрах. В осередках таблиці розташовуються $\{0,1\}$. Символ 1 - відповідає зайнятому квадратному метру площі, символ 0 - не зайнятому.

Пошук позиції для розміщення починається 3 пошуку зайнятих місць 3 даної номенклатурою. Для цього 3 бази даних вибирається запит «Отримати адреси місць розміщення і зайнятий обсяг, у яких код металопрокату $=\ldots$ i номер сектора $=\ldots$... Формується список місць зберігання такої ж номенклатури.

Згідно з довідником «Геометричні параметри по пачках номенклатурних позицій і їх вага» ми отримуємо максимальний обсяг для даної номенклатури $-V_{j, i}^{\max }$, який може бути розміщений в одному місці зберігання. використовуючи формулу (9), проводиться розрахунок кількості одиниць номенклатури $N_{j, i}^{\text {ном }}$, які можна додати у вже зайняті місця (представлені в списку).

$$
N_{j, i}^{\text {ном }}=\text { ЦІЛЕ }\left(\frac{V_{j, i}^{\max }-V_{j, i}^{\text {зан.ном }}}{V_{j, i}^{\text {ном }}}\right)
$$

де $V_{j, i}^{\max }$ - максимальний обсяг для j-ої номенклатури, який можна розмістити в одному місці зберігання (в тонах);

$V_{j, i}^{\text {зан.ном }}-$ обсяг, який займає металопрокат, в одному місці зберігання ј-ой номенклатури (в тонах);

Режим доступу: http://sap.pstu.edu 
$2019 \mathrm{p}$.

\section{Інформаційні технології}

Вип. 20

$V_{j, i}^{\text {ном }}$ - обсяг ј-ої одиниці номенклатури (в тонах).

Так як нумерація місць зберігання починається з одиниці і зростає в бік віддалення від місць завантаження / розвантаження, то список потенційних незаповнених до кінця місць зберігання сортується за двома параметрами послідовно:

- якщо поточна номенклатура групи А, то по зростанню ряду і зростанню кількості одиниць номенклатури $\mathrm{N}_{\mathrm{j}, \mathrm{i}}^{\text {ном }}$, які можна додати у вже зайняті місця;

- якщо поточна номенклатура групи В або С, то по спаданню ряду і зростанню кількості одиниць номенклатури $\mathrm{N}_{\mathrm{j}, \mathrm{i}}^{\text {ном }}$, які можна додати у вже зайняті місця.

Після цього відбувається формування рекомендації для розміщення номенклатури в кількостях $\left(N_{j, i}^{\text {ном }}\right)$ зазначених у списку для кожної позиції. Місця зберігання, в яких $N_{j, i}^{\text {ном }}=0$ зі списку виключаються. Якщо кількості наявних місць зберігання недостатньо, то залишок номенклатури розподіляється на вільних місцях, маючи в своєму розпорядженні на одне місце кількість, яка не перевищує $N_{j, i}^{\text {ном.max }}$ (формула 10 ).

$$
N_{j, i}^{\text {ном.max }}=\text { ЦІЛЕ }\left(\frac{V_{j, i}^{\max }}{V_{j, i}^{\text {омм }}}\right)
$$

де $V_{j, i}^{\max }$ - максимальний обсяг для ј-ої номенклатури, який можна розмістити в одному місці зберігання (в тонах);

$V_{j, i}^{\text {ном }}$ - обсяг, одиниці номенклатури (в тонах).

Пошук вільної площі для розміщення здійснюється як в разі нестачі наявних місць зберігання, так і в разі відсутності даної номенклатури в даному секторі складу в принципі. Якщо номенклатура має групу А, то пошук починається з початкового ряду в порядку зростання, якщо групу В або С, то з кінцевого ряду в порядку убування рядів. На рис. 1 показано стрілками напрямок обходу для пошуку вільного місця для номенклатури групи А.

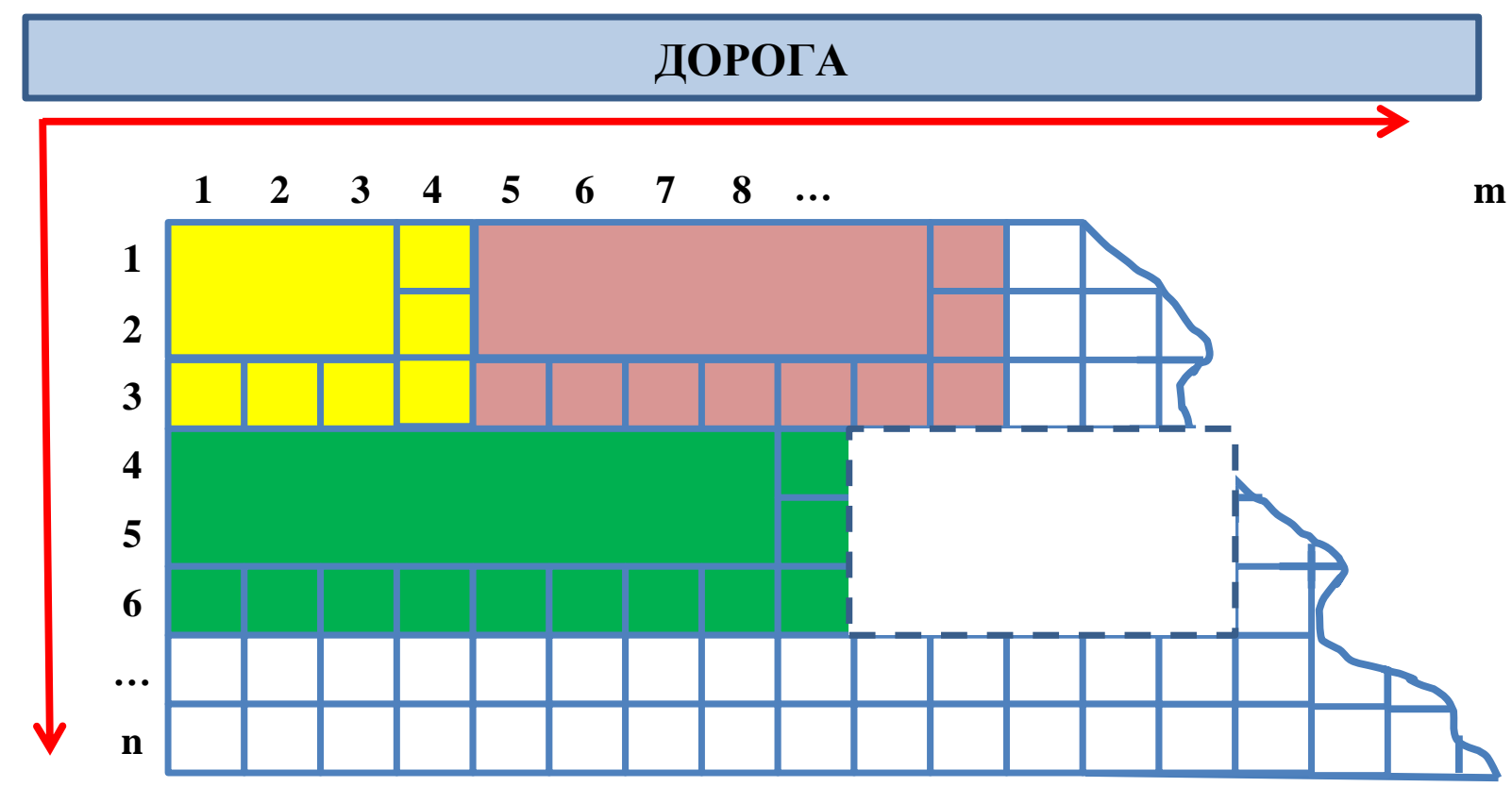

Рисунок 1 - Напрями пошуку вільного місця зберігання при розміщенні номенклатури групи А

Режим доступу: http://sap.pstu.edu 
$2019 \mathrm{p}$.

\section{Інформаційні технології}

Вип. 20

3 рисунка також видно, що до розміщеної номенклатури по довжині і ширині в напрямку збільшення додано по одному ряду, це зроблено для забезпечення проходів між місцями зберігання, прохід становить рівно один метр.

Система перебирає в циклі ряди, в кожному ряді послідовно переглядає комірки, тобто по суті, відбувається повний перебір комірок в напрямку вказаному вище. Як тільки вона знаходить більш однієї вільної комірки в ряду (комірка вільна, якщо в таблиці-схемі розміщення номенклатури відповідне їй значення дорівнює нулю), проводиться підрахунок вільних комірок.

Причому вільними повинні бути і комірки двох сусідніх рядів, це пов'язано з тим, що номенклатури мають прямокутну форму з шириною 1,5 і 2 метри, додавши до них 1 метр безпечного проходу, отримуємо область 3 фіксованою шириною - 3 метри і завдовжки в залежності від довжини номенклатури, що розміщується (див. рис.2, прямокутна область позначена штрих пунктиром).

Якщо довжини вільного простору недостатньо, то пошук починається 3 наступного ряду (наступним буде ряд через два після попереднього). Якщо всі ряди переглянуті, і вільне місце не знайдено, то система перейде до наступного, менш завантаженого сектору i продовжить пошук там. У разі успіху, комірка позначається як зайнята прямокутна область, яка рекомендується оператору-комірникові для розміщення номенклатури.

Даний алгоритм для наступної номенклатури повторюється. Система дозволяє вводити по одній номенклатурі, і знаходити для неї вільні місця розміщення, або списком номенклатури, в такому випадку, вона формує рекомендацію зі схемою розміщення. Приклад схеми наведено на рис. 2.

На рис. 2 зайняті місця зафарбовані кольором, в рекомендованих вільних місцях зберігання записані коди номенклатури і адреси комірок за наступною схемою:

$\mathrm{S}<$ Номер сектора $>$ : <номер ряду лівої верхньої комірки>: <номер стовпчика лівої верхньої комірки>: <номер ряду правої нижньої комірки>: <номер стовпця правої нижньої комірки>

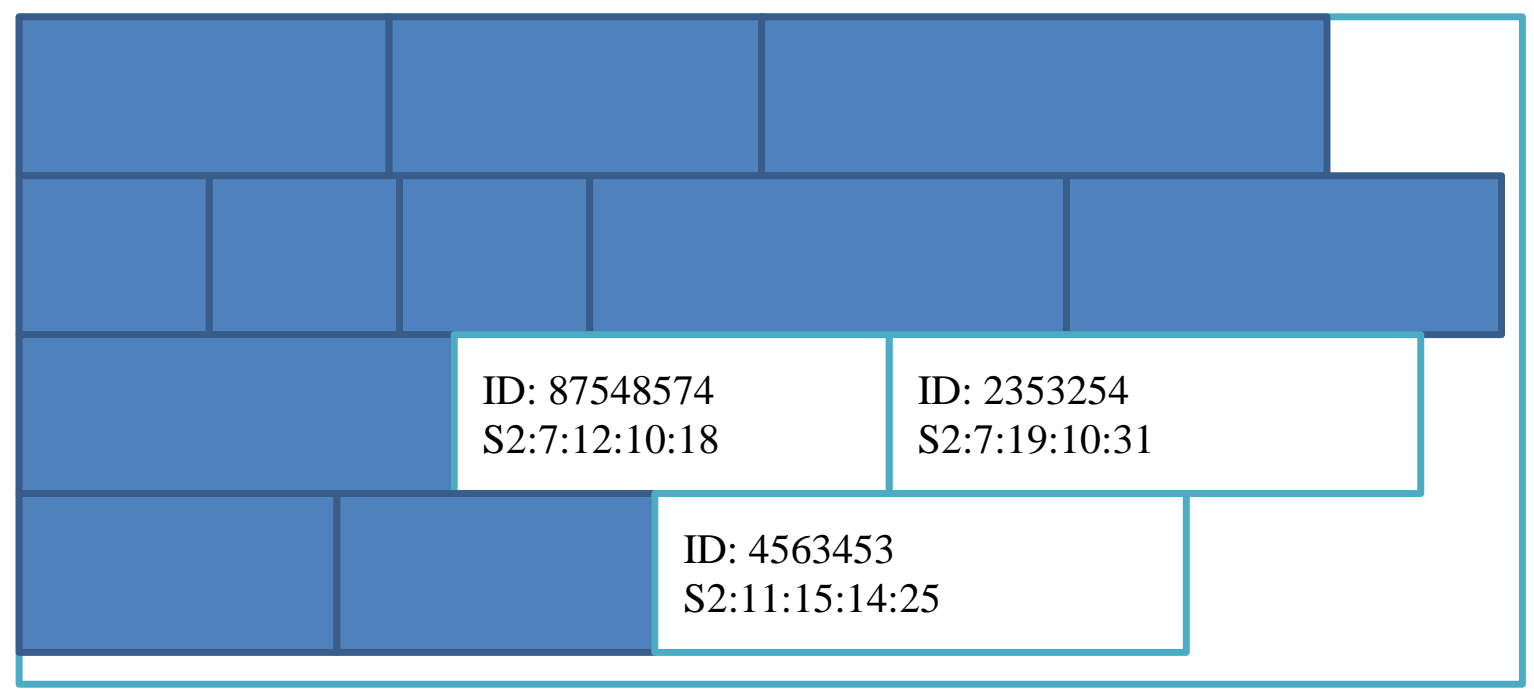

Рисунок 2 - Схема розміщення

Як видно, номенклатури розташовуються максимально щільно один до одного 3 мінімальними залишками вільної площі.

Режим доступу: http://sap.pstu.edu 
2019 p.

\section{Інформаційні технології}

Вип. 20

Кількість залишків вільної площі в рядах можна зменшити, якщо не послідовно перебирати номенклатури, а підбирати номенклатуру під кожний вільний простір 3 використанням інтелектуального алгоритму. Але так, як транспорт доставляє, як правило, обмежену кількість різної номенклатури, то відсутній в принципі вибір.

Показники ефективності заповнення складу. Основними критеріями оцінки рентабельності моделі складування є показники ефективності використання складських площ і обсягів:

- коефіцієнт використання площі складських приміщень:

$$
\mathrm{K}_{\mathrm{S}}^{\text {исп }}=\frac{\mathrm{S}^{\text {зан }}}{\mathrm{S}^{\text {общ }}}
$$

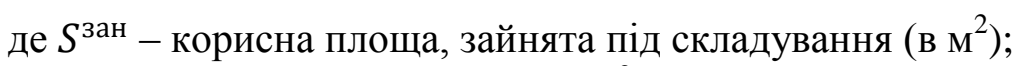

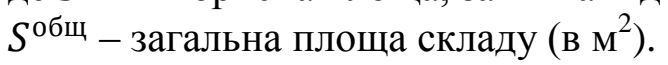

$$
S^{\text {зан }}=\sum_{i} S_{i}^{\text {зан.сек }}
$$

де і - ідентифікатор корисних секторів на складі (наприклад, на СМЦ Маріуполь сектора № 4, 8, 12, на СМЦ Партизанське - № 1, 4, 8);

$S_{i}^{3 а н . с е к ~}-$ корисна площа, зайнята під складування у відповідному секторі.

$$
S^{\text {общ }}=\sum_{i} S_{i}^{\text {общ.сек }}
$$

де і - ідентифікатор корисних секторів на складі (наприклад, на СМЦ Маріуполь сектора № 4, 8, 12, на СМЦ Партизанське - № 1, 4, 8);

$S_{i}^{\text {общ.сек }}$ - загальна площа відповідного сектора (в $\left.{ }^{2}\right)$.

$$
S^{\text {зан.сек }}=\sum_{j} S_{j}^{\text {зан.ном }}
$$

де $j$ - код металопрокату на складі;

$S_{j}^{\text {зан.ном }}-$ площа, яку займає металопрокат $\left(\right.$ в м $\left.{ }^{2}\right)$.

$$
S_{j}^{\text {зан.ном }}=\left(l_{j}^{\text {ном }}+1\right) \cdot\left(w_{j}^{\text {ном }}+1\right)
$$

де $l_{j}^{\text {ном }}$ - довжина місця в метрах, під зберігання ј-ої номенклатури;

$w_{j}^{\text {ном }}-$ ширина місця в метрах, під зберігання ј-ої номенклатури.

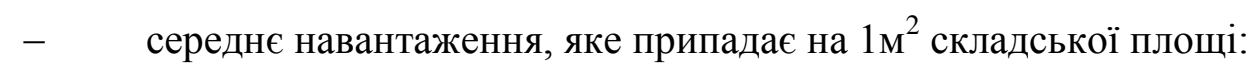

$$
\mathrm{K}^{\text {ср.наг }}=\frac{\mathrm{V}^{\text {зан }}}{\mathrm{S}^{\text {общ }}}
$$

де $V^{\text {зан }}$ - корисний об'єм, зайнятий під складування (в тонах);

Режим доступу: http://sap.pstu.edu 
$2019 \mathrm{p}$.

\section{Інформаційні технології}

Вип. 20

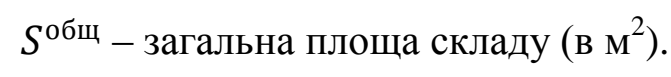

$$
V^{\text {зан }}=\sum_{j} V_{j}^{\text {зан.ном }}
$$

де $j$ - код металопрокату на складі;

$V_{j}^{\text {зан.ном }}-$ об'єм, який металопрокат займав в одному місці зберігання ј-ої номенклатури (в тонах).

- коефіцієнт використання об'єму складу:

$$
\mathrm{K}^{\text {ср.наг }}=\frac{\mathrm{V}^{\text {зан }}}{\mathrm{V}^{\text {общ }}}
$$

де $V^{3 а н ~}-$ корисний об'єм, зайнятий під складування (в тонах);

$V^{\text {общ }}$ - загальний об'єм складу (в тонах).

- вантажонапруженість номенклатури:

$$
\mathrm{K}_{\mathrm{j}}^{\text {нап.ном }}=\mathrm{K}_{\mathrm{j}}^{\text {Пл }} \cdot \mathrm{K}_{\mathrm{j}}^{\text {об }}
$$

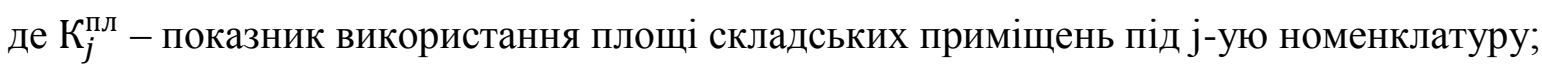
$\mathrm{K}_{j}^{\mathrm{o \sigma}}$ - коефіцієнт оборотності ј-го металопрокату.

$$
\mathrm{K}^{\text {ср.наг }}=\frac{\left(\sum \mathrm{S}_{\mathrm{j}}^{\text {зан.ном }}\right)}{\mathrm{S}^{\text {общ }}}
$$

де $S_{j}^{\text {зан.ном }}$ - площа, яку займає ј-м металопрокат (в м²);

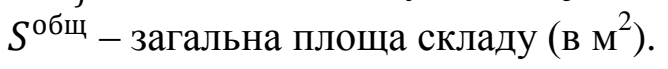

\section{ВИСНОВКИ}

Реалізація даної моделі дозволяє сформувати схему розміщення металопрокату на складі готової продукції. Дана схема враховує раціональне розміщення по ряду показників. Використання даної моделі при розробці програмного забезпечення дозволить отримати сучасну рекомендаційну систему або частина інтелектуальної системи управління складом.

\section{Перелік використаних джерел:}

1. Шандрівська, О. С. Логістичний менеджмент : практикум / О. С. Шандрівська, В. В. Кузяк, Н. І. Хтей. - Львів : Вид-во Львів. політехніки, 2014. - 192 с.

2. Крикавський, Є. В. Матеріальні потоки у логістиці промислового підприємства : монографія : присвячено 170-літтю Нац. ун-ту «Львів. Політехніка» та 70-літтю каф. маркетингу і логістики / С. В. Крикавський, Н. М. Васильців, В. А. Фалович.- Львів : Вид-во Львів. політехніки, 2015. - 252 с. 


\section{Інформаційні технології}

3. Илесалиев, Д. И. Обоснование проекта сети терминалов тарно-штучных грузов / Д. И. Илесалиев // Научно-технических вестник Брянского гос. Ун-та. - 2016. - № 4. - С. 110 117.

4. Коровяковская, Ю. В. Складские комплексы как элементы логистической цепи / Ю. В. Коровяковская, О.Б. Маликов // Вестник инженеров электромехаников железнодорожного транспорта. - 2003. - № 3. - С. 222-224.

5. Кузнецов, А. Л. Расчёт вместимости портового склада с учётом неравномерности работы смежного транспорта / А. Л. Кузнецов, В. А. Погодин, Я. Б. Спасский // Эксплуатация морского транспорта. - 2010. - № 4. - С. 3-9.

6. Лобанов, Н. Б. Методика расчёта потребности в складских площадях / Н. Б. Лобанов // Транспорт Российской Федерации. - 2007. - № 1 (54). - С. 6-9.

7. Григоренко, В. М. Доменный метод размещения штучных грузов в современных складах / В. М. Григоренко // Вестник ИНЖЭКОН. Серия: Экономика. - 2010. - № 4. - С. 2133.

8. Григоренко, В.M. Оптимизация размещения штучных грузов в складах стеллажного хранения по «методу Griko» / B. М. Григоренко // Логистика : современные тенденции развития : материалы XIV Междунар. научно-практ. конф. (Санкт-Петербург, 910 апреля 2015 г.). - СПб., 2015. - С. 132-133.

Мироненко Д. С., Буц Ю.В.

\section{МАТЕМАТИЧЕСКАЯ МОДЕЛЬ «РАЗМЕЩЕНИЕ МЕТАЛЛОПРОКАТА НА СКЛАДЕ ГОТОВОЙ ПРОДУКЦИИ »}

В статье проведен анализ сущзествующих моделей размещения металлопроката на складах готовой продукции, среди методов эффективного размещения выбрано использование метода АВС анализа.

АВС-анализ на складе - метод, позволяющиий классифицировать запасы металлопроката по степени их важности путем деления на три категории. В качестве критерия классификаџии предложено использовать коэффициент оборачиваемости металлопроката.

Приведен алгоритм размещения металлопроката на частично заполненном составе. Выбор сектора для размещения определяется по наименьшему значению загруженности в текущий момент времени. Целевое хранения номенклатуры в одном месте хранения - не более 2-х позиций. При расчете учитывается наличие сепарачии (деревянных прокладок) между пачками номенклатурных позищий. Целевое значение по ширине складской площади один метр между четырьмя местам хранения. Целевое значение по длине складской площади - один метр между местами хранения. Распределение складов на сектора учитывает зоны хранения инвентаря и зоны сервисной обработки (резка) продукиии.

Для оценки эффективности математической модели введеньл следуюшие коэффициенты: коэффициент использования площзади складских помещзений, коэффициент использования объема склада, грузонапряженность номенклатуры.

Ключевые слова: металлопрокат, склад, математична модель, АВС анализ 
2019 p.

\section{Інформаційні технології}

Mironenko D. S., Buts Y. V.

\section{MATHEMATIC MODEL «PLACEMENT OF METAL PROCESSING ON THE STORAGE OF FINISHED PRODUCTS»}

The article describes the mathematical model of the location of metal rolling in the warehouses of finished products. The mathematical model will enable the arrival of metal rolling in the warehouse at each position to search for the appropriate location, taking into account the category of $A B C$ analysis, geometric features, storage method and the number of metal rolling. $A B C$-analysis in stock is a method that allows to classify the stocks of metal rolling by their degree of importance by division into three categories. As a criterion for classification it is suggested to use the coefficient of turnover of metal rolling.

An algorithm for placing metal rolling in a partially filled warehouse is presented. The choice of the sector for placement is determined by the lowest load value at the current time. Target storage of the nomenclature in one place of storage - no more than 2 positions. The calculation takes into account the presence of separation (wooden gaskets) between bundles of nomenclature items. The target value for the width of the warehouse space is one meter between the four places of storage. The target value for the length of the warehouse space is one meter between storage locations. The division of warehouses into sectors takes into account inventory storage areas and service processing (cutting) areas of products. Mathematical model of metal rolling placement in finished goods warehouses. One of the main indicators of the efficiency of the warehouse enterprise is the turnover of stocks of rolled metal. Inventory turnover ratio is the ratio of stock shipments to its assets (balances). This indicator makes it clear how quickly the stock that is in stock is consumed. The inventory turnover ratio shows how efficiently and successfully an entity uses its assets to generate revenue.

The following coefficients have been introduced to evaluate the efficiency of the mathematical model: the coefficient of use of the warehouse space, the coefficient of utilization of the volume of the warehouse, the cargo tension of the nomenclature.

Keywords: metal rolling, storage,, mathematical model, ABC analysis, efficiency factor

Рецензент: доцент, канд. техн. наук Левицка Т. О.

Стаття поступила 15.01.2019 p. 